\title{
ON REALITY, TRUTH AND IDEOLOGIES IN THE CASE OF MUNCHAUSEN TALES ${ }^{1}$
}

\author{
Eda Kalmre
}

\begin{abstract}
This article studies the way the meaning of a tradition has changed over time. It is based on four text samples, all representing similar motives. The story reflects a former popular belief that if you hold on to a wild animal's tail, the animal will jump clean out of its skin. The Man Nails the Tail of a Wolf to a Tree (ATU 1896) is a popular folk tale with an international distribution. Texts of this type have also been called Munchausen tales. The changed message of similar traditions reflects the change in our attitude towards nature, but also the growing distance of man from nature.
\end{abstract}

Keywords: animal abuse, comic legend, joke, Munchausen tale, social narrative, tall tale, urban legend

In the modern world, folktale texts reach us through various channels: they are spread in oral communication, and can be read in fiction books, on the Internet and in the written press. We can listen to these texts, read and sometimes even watch their adaptations in television programmes, feature films and theatre plays in the visual media. For a folklore researcher, issues of texts and their relation to the tradition are as important as the issues of the context and meaning in these texts.

The folkloric text, once learnt and stored in the memory, be it a small product remembered verbatim or a longer narrative that can be reproduced according to a plot scheme and key lines, is in its latent inactive state in the mind, open or devoid of meaning. Yet the situation, in which the product enters the consciousness, is recalled, actualised, produced and performed, is full of meaning. (Honko 1986a: 99)

Why do some old and well-known stories/texts keep reappearing every now and then, what is their meaning for us, and what is the message they convey? Does the meaning of a text change in time, and if so, to what extent? 
In defining the meaning of a narrative, the time-related ideologies of narrators, of their audiences and also of researchers play a crucial role. The genres are also dominant factors in the organisation of communicating tradition.

Genres could be conceived of as units of communication which focus, direct and limit meaning, favour some and avoid other topics, regulate expression and encourage typical ways of speech and action. (Honko 1986b: 52)

Several researchers have pointed out that while the Märchen incorporates narrative motives into an artistic story, the legend employs them as credible facts (e.g. Dégh 1971: 62).

The contextual approach suggests that in folklore texts are more stable than their meanings (Honko 1986b: 40). Researchers of narratives are generally aware of the fact that the meaning of a text is relative, that their interpretations are subjective and may change in time.

Consequently we may well question the validity of such fixed constructs of interpretation and of the "evidence" they produce. The history of ideologies can be read from that of interpretations. The meaning of text is not a fixed constant but is a variable, determined by the development of culture and ideas, fashions and trends, and dependent on rules and ruling ideologies, not to forget the education and cultural awareness, the sex, age, religion and ethnic group of the consumer. Cultures are systems of meaning. (Röhrich 1986: 128)

The same narrative can be interpreted in different ways in different times and cultures, yet some functions remain constant over time. Narratives can have an individual, a narrator-centred and a general level of meaning. In belief legends it is the expression of fears and anxiety, and in fairy tales the repression of fears and the fulfilment of wishes and dreams.

New meanings are continually being given to traditional folk material. The question is whether these new forms can have the same meaning for urban societies as the traditional oral genres did for another time? (Röhrich 1986: 129)

Carl Lindahl has observed the mechanism of such modifications while comparing contemporary legends and older archival materials and has claimed that according to certain legend plots, the solution of the story is unambiguous; it has a single possible interpretation. The characters are either good or bad, and operate according to clearly understood moral norms. However, in the case of the modern counterparts of the same archival texts, the interpretive rules are much more complicated. One situation can have more than one possible solutions and one symbol can have several contradicting meanings (Lindahl 1996). 
But what could we learn by observing texts with similar motifs emerging at different times? The following discussion is an attempt to interpret a message from a well-known folktale, which has changed in time, by observing both the text and the context around it. This means that although my viewpoint on this material is comparative and to some extent proceeds from the semantics of folktale genres, the following approach can rather be essayistic due to the small number of comparable texts. Genres are treated here mainly as different discourses, each one of them having their own rhetorical features, vocabulary, position in reality, use of descriptive language, character types and dominant symbolic meanings. In case a narrative motif or topic has become part of such a complex, it is subject to the rules prevailing within the form of the discourse (Ben-Amos 2009: 132-133).

In this article, one of the essential starting points for interpreting the material is the narrators' attitudes towards the subject matter - i.e., what is the position of the narrative in reality, to what extent it should be believed. In reality, these borders are not really strictly established, especially if we talk about legends (or their modern counterparts - urban legends) and jokes. While a legend as the carrier and verifier of religious information is related to folk belief, then "a 'joke' is defined as brief, humorous folktale, usually containing only a single episode and ending with a punch line. The line between joke and legend blurs even further with urban legends that acquire a punch line ending. In practice, some humorous urban legends are frequently told as jokes, with the teller indicating by performance style (tone of voice, facial expression, gestures, etc.) that he or she regards the story as mere fiction" (Brunvand 2002: 223).

In the case of the following material it is noteworthy that contemporary or urban legends can be regarded as a media genre due to their similarity to the news. As a matter of fact, many stories considered to be folklore can today be found in newspapers as sensational news or urban canards, in which reality is full of dangers and risks and the most fantastic or extraordinary cases are made credible by the testimonies of the alleged eye-witnesses (Virtanen 1996: 250-252).

As regards the creation of credibility, although ostensible, legends feature the same genre characteristics as tall tales (ATU 1875-1999). These are narratives that start in a realistic key; yet, they have an unpredictable and humorous climax verging to absurdity. Tall tales are often told so as to make the narrator seem to have been a part of the story. These are, for example, the popular Munchausen tales ${ }^{2}$ widely known from literary works, as well as various other tall tales. Actually, narrating of these kinds of tall tales is an old tradition and was initially related to the art of story-telling inherent in people remarkable for 
something in the communities of travellers, hunters, merchants, etc. Richard M. Dorson (1939) called these stories comic legends (see also Ben-Amos 1976: 25).

The following argumentation attempts to make sense of the development of the message of a well-known folk narrative, while taking into consideration the text (the genre) as well as the context that surrounds it. The text that could be regarded as an urban legend attracted my attention a few years ago while reading a brief news piece from the Baltic News Service (BNS). While examining the several source texts of this legend, I focus on the following questions: 1) what message they convey, and how these texts are related to reality, and also 2) how these texts reflect people's attitudes towards nature and animals.

\section{MATERIAL}

The narrative presented here first (1) could be classified as a journalistic version of an urban legend, which was depicted by the author as a real-life event with eyewitnesses. Namely, in 2005, the Estonian police launched an investigation on the basis of a newspaper article. According to the author of this article, in the town of Pärnu in the southwest of Estonia, some boys skinned cats by making a T-shaped cut into a cat's face and while holding onto a short piece of rope tied to the cat's tail, threw it from the roof, so that the cat's skin peeled off over its ears. Allegedly, the boys had killed at least six cats this way.

The results of the police investigation were published on March 9, 2005, as a BNS news piece entitled "Article on Cat-Slaughter Based on an Urban Legend" (Artikkel kasside tapmisest põhines linnalegendil, BNS 2005). The police spokesman asserted that the article had been inspired by a conversation between two girls, during which one girl had told her friend similar stories about cats and blowing up of frogs. The mother of one of the girls had overheard the conversation and was so shocked by the cruelty of the children that she wrote an article to the local newspaper. This was the very article that triggered the police investigation. The police concluded upon consulting with experts that animals could not be skinned in this manner.

This shortly summarises the brief news piece that I happened to read some time after it was published. Further investigation revealed the original source that had inspired the confusion. It was published in Russian in the newspaper Molodezh' Estonii (Youth in Estonia) in the section SOS under the headline 'Kotovasiia's iunykh potroshitelei (Trouble with Cats and Young Rippers) (Kollom 2005). The article took up almost an entire page and consisted of three individual parts. In the first part Inessa Kollom, the author of the article, described the schoolboys' gory deed which was allegedly witnessed by a schoolgirl who had 
happened to walk her dog nearby this evening. The incident was described very realistically and readers were taken aback by the disgusting images of the sadistic torture of animals, the suffering victims and the ruthless boys.

The picture that I saw was beyond one's imagination. A cat was lying in a pool of blood and growled, trying to crawl out of its skin. The cat's tail was tied to a tall rope that was suspended from the roof. One could hear barbaric laughter from the rooftop. (ibid.)

In the second part of the article, more details are added to the description. The author notes that the torturers were high-school boys at the age of 14-15, but gives no further information about the persons of the boys or the school they were from, claiming that the boys' faces had not been seen.

The third part of the article is edifying and explores the issue of adolescent aggression and whether it is an innate or an acquired phenomenon.

And this is our future. Now they are tormenting cats, later they will become total maniacs who kill women and children... Indeed, our youth has been badly infected by the "A-virus" - aggression. (ibid.)

The author concludes that it is not a matter of instincts, but the problem is caused by deficiencies in the upbringing of the modern youth. The dramatic content of the article is further emphasised by a picture collage by Vladimir Pryadilshchikov, which depicts a small black kitten, with a big bloody wrench hanging over it. The latter represents as if live evil, having an eye drawn to it. The tragic tonality of the picture is still emphasised by crimson trickles in the middle of the picture and along margins.

The above-cited story largely resembles an old folk tale which says that if you hold on to an animal's tail, it can jump out of its skin in fear. "The Man Nails the Tail of the Wolf to the Tree", ATU 1896, is a tall tale of international spread that has been called a Munchausen tale. The second text example (2) in this article, entitled "Seven Horseshoe Nails", originates from here. Estonian folklorist Mall Proodel-Hiiemäe has included "Seven Horseshoe Nails" in her anthology of hunter's tales, noting that this tale type seldom occurs in Estonia. Usually, international tall tales inspire abundant local compilations, but in this case we can talk of a simple reproduction of a classical tall tale (Proodel 1969: 23).

\section{Seven Horseshoe Nails}

I went to the woods once, and found seven horseshoe nails lying on the ground. Since I knew that the nails were supposed to bring luck, without thinking further I put them in my pocket. Suddenly I see a big tree stump, and seven wolves resting nearby after their meal. I ponder: if I 
go to look for help, they will wake up and leave, but with a little trick, I will be a wealthy man at once. Suddenly an idea came to me. I took all the seven horseshoe nails, pinned each wolf's tail to the stump, then banged with a cudgel against the tree and barked. Lo and behold - as if they had been stung, all the wolves jumped up and took off towards the woods, but forgot their tails pinned to the stumps and so they jumped out of their skins. Pity about the meat, but it couldn't be helped; I had to be satisfied with the skins. (RKM II 155, 159/60)

It was quite common that a story-teller's repertoire would include several stories fitting with the distinct image of either a traveller or a hunter. This kind of tall tales formed entire series. So, there is also another story told by M. Sikk (born in 1877), the narrator of "Seven Horseshoe Nails".

Bitter cold

On an early Sunday morning, I went to the woods. I had heard that it was hare-shooting season, and I thought I would try my luck. Suddenly I saw a hare. I banged once, twice, third and fourth time, but the hare paid no heed. I understood that it was frozen. I gathered a pile of twigs, made fire, waited until the hare warmed up. And when I took another shot, the hare kicked the bucket at once. (RKM II 155, 161)

The third (3) similar motif of a tall tale or a hunter's tale ("Hunter Turns Animal Inside Out", ATU 1889B ${ }^{4}$ ) can be found in a collection of anecdotes published during the Soviet period. The story was recorded from a live performance in 1975 .

How to Catch a Bear?

???

You dip your hand in honey, the bear comes and starts licking your hand. You stick your hand really deep, so deep that you grab the bear's tail through the backside and turn the bear inside out. (Viikberg 1997: 358)

In the $1990 \mathrm{~s}$, it became evident to me that the cat story was highly popular in Estonian school lore repertoire. Several schoolboys wrote it down for the school lore collection in 1998. Below is an example (4) from the Estonian Folklore Archives, narrated by a 13-year-old boy.

An annoying cat kept returning to the stairway. People had repeatedly thrown turpentine on its back. The cat had then scurried away and sat down on its behind, and pulled itself forward with front paws. As the cat would not leave, the boys living there had enough of it and tied a rope around the cat's neck and threw the cat out the window. Holding on to one end of the rope, the cat reportedly jumped out of its skin. A chunk of meat fell on the ground. 


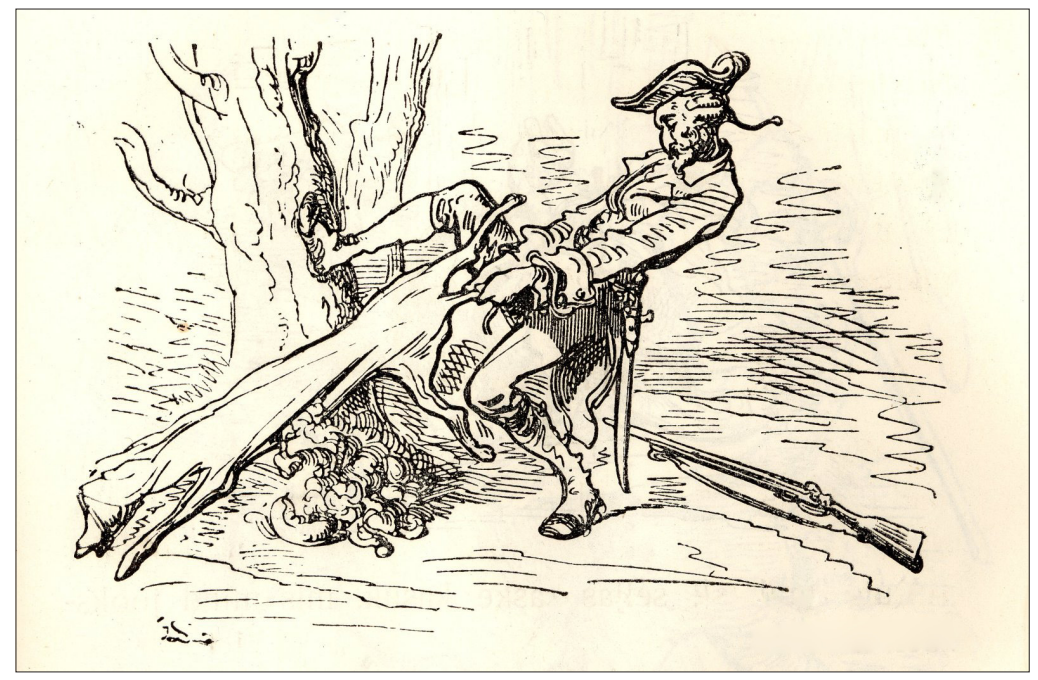

Figure 1. Illustration to the tale "Turns Wolf Inside Out" by Gustave Doré in the Russian translation of Rudolph Erich Raspe's book "The Adventures of Baron Munchausen”, Moscow \& Leningrad 1936.

In the context of the above text, a further comment is in order: I had a discussion with my then teen-aged daughter on this topic. The story was familiar to her: she had heard a similar tale from her classmates, the boys who had insistently teased the girls on a class excursion by telling the story. Neither the narrators nor the listeners doubted the feasibility of the incident. We can suppose that the girls whose story had inspired Inessa Kollom to write her article had heard a similar story from some boys they knew.

\section{THE MAGIC AND THE REALITY OF THE TALL TALE}

While observing how all these stories that describe cases of animal abuse fit into their time and context, we should first specify that the four texts described above can be associated with somewhat different contexts and time periods. The tall tale presents the milieu and ideas of an agrarian culture. In this storyworld, both small and big miracles are possible: in this case the magical number of the lucky horseshoe nails and the same number of sleeping wolves who did not wake up even after their tails were pinned to the stump. The first-person narrator thought that it was a pity that the meat was lost, but the seven wolf skins cost a fortune in this world. 
The Munchausen tales were amusing lie stories which were based on the tradition and the storyteller's imagination. In the twentieth-century lore of hunters, foresters and lumber jacks, tall tales were mostly told as first-person narratives, or as personal experience stories. In the case of the tall tale, the storyteller takes on the role of a con artist who intentionally fools the audience. First-person narration made the story appear reliable, and the audience appreciated the fantastic end that arrived by unusual means and a sheer chance. This was for the sake of a good joke and at the same time of having a laugh at those among the audience who took the joke seriously.

Telling such a joke is a culturally determined form of communication, which usually differs from everyday mediation of information. The joking frame appears to be a negotiated domain. Its license must be sanctioned by both the performer and the audience. Thus, jokes and joking performances, like any other form of cultural production, are enmeshed within socio-cultural power relations that they simultaneously map and disrupt (Preston 1997: 471).

Mall Proodel-Hiiemäe, who has examined such stories in their natural performance context, emphasises that in tall tales the effect of the story indeed aimed to take advantage of the ignorance of the audience. The story, however, was successful only as long as it was told as fiction and accepted as such by the audience (Proodel 1969: 23). Solutions that cannot be used in real life operate perfectly well in tall tales. Dan Ben-Amos, who has studied these tall tales in Jewish culture, argues that this genre has been perceived as a special story form and these stories had culturally restrictive borders, which established the topics suitable for narrations. In the narrating of such stories, the social role of the narrator is extremely important. The special reputation gained by the experience of a traveller or hunter entitled them to exaggerations and therefore, their tales and lies could have been subjected to the social convention of common agreement, which lends the stories a hint of reality. In case any of the figments failed to correspond to the culturally recognised genre prescriptions, it emerged from the rest of the material as a breach of cultural norms. At the same time, the same genre characteristics that the narrators formulated and perceived in the active period of the story tradition, symbolically passed on the special mutual influence between the seeming reality and real make-believe of the stories (Ben-Amos 2009: 286).

The audience of the comic legend, who were familiar with the life and physiology of animals, forgot for a moment what they knew and enjoyed the style, fantasy and covert humour of the story set in the familiar context. The audience appreciated the lie for the sake of a good story; therefore the old tall tale was not perceived as cruel or violent. The story leaves the impression that the wolves who are able to flee into the forest can obviously cope in life even with- 
out their skins - as it is the case in many fairy tales that tell about animals, or more exactly, about humans disguised as animals who leave their skins on a big stone and come to breast-feed their human children or visit their human relatives at home.

In most hunter and war stories that were allegedly told by Munchausen, the incidents with animals tested the limits of the audience's perception, morality and good taste. So did the strange beasts resembling the hare with eight legs, or the bear that swallowed the carriage beam in its greed for honey, or Munchausen's horse that had lost half of its body in battle, and was no longer watertight.

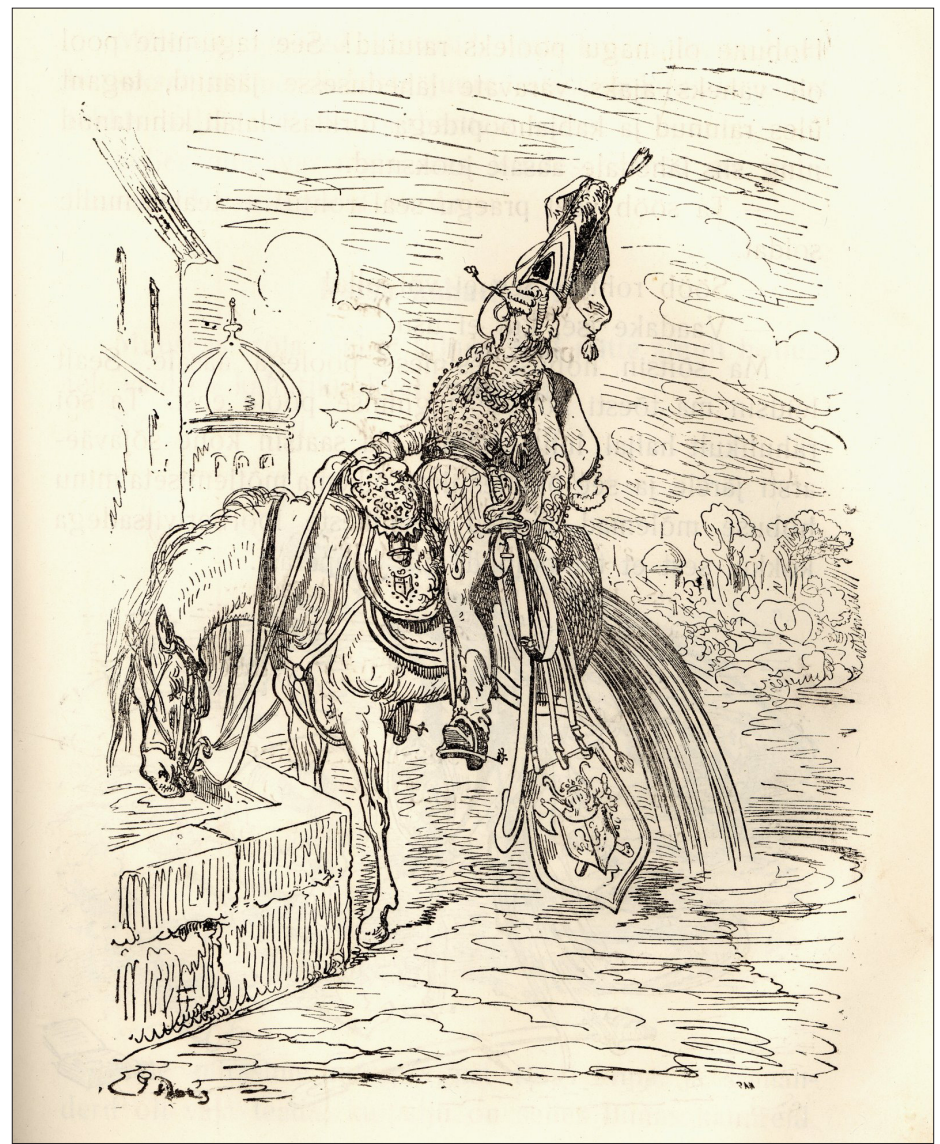

Figure 2. Illustration to the tale "Half a Horse" by Gustave Doré in the Russian translation of Rudolph Erich Raspe's book "The Adventures of Baron Munchausen”, Moscow \& Leningrad 1936. 
The moral balance in these seemingly cruel plots is maintained through the interaction of humour and fantasy. The fore part of Munchausen's horse finds its hind part in a meadow, and the farrier sews them together with young shoots of laurel, so that a mighty laurel wreath grows around the horse's head.

Small and big miracles that are born in the interrelation of the narrator and the tradition occur in the tale along with pragmatism. Whatever tricks are used to catch the prey, a prey is still a prey, because these tales reflected a world in which only the clever and inventive ones merited survival and real success. If you wanted to survive, you had to be cleverer and sturdier than the animal. Thus, the tales teach us how to turn a bear inside out by sticking the hand into its maw, or how to suffocate a bear or a wolf by sticking the hand deep into the animal's throat, so that it is unable to shut its mouth.

\section{THE AMBIGUITY OF THE CONTEMPORARY MUNCHAUSEN STORY}

The contemporary versions of the old tall tale that emerge as part of children's and media culture are an evidence of the possible manifestations and applications of folklore in the modern culture. For a contemporary man, the motive of an animal turned inside out like a fur coat seems absurd rather than as a situation intrinsic to a comic legend "referring to the special mutual influence between the seeming reality and real make-believe". The modern shorter equivalents of (or the narratives functionally closest to) the tall tale seem to be riddle-like anecdotes with an absurd punch line (see Text 3 ). These texts do not provide the audience an answer; the emphasis in the text lies in the humour that results from the absurdity and unexpectedness of the situation. Text 4, which has been recorded from children, suggests that the customs, practices, tale and belief traditions, etc., which have become secondary in adult lore, have been passed on to and adopted by the children's culture. Continuing its existence in the children's culture, the Munchausen tale has acquired an (additional) function of determining social relationships within the group. The aggressiveness in the children's folklore and the narrator's intent to evoke in the audience a sense of disgust and disapproval is mostly introduced for the purpose of seeking attention and superiority. This is obviously also one of the reasons why the story usually belongs to the repertoire of boys. Here the story has maintained part of its older narrating function; one of the motivations of the narrator of the hunter's tale was clearly the same. 
Observing the changes in the meaning and the function of the example texts, we have to agree that the modifications are most remarkable in the proportions of how the reality has been presented. Like the contemporary media text and the children's horror story, the older tall tale has taken the form of a belief legend that tells about cat torture in towns and blocks of flats. The older folk tale not only describes the reality, but also creates something more. The Munchausen tale was first and foremost an enjoyable lie that did not pretend to be true and as such represents one of the most significant differences between the tall tale and its modern developments.

The modern texts narrate about animal abuse as a social phenomenon and a form of human aggression. The shocking and detailed witness descriptions in the first media text sound like testimonies of a Munchausen syndrome ${ }^{5}$ sufferer; through the description of violence and disgusting details the narrator tries to draw attention to himself and convey a clearly moralising message, whatever the cost.

In our increasingly urbanising culture, these texts reflect the general lines of development in the modern practices relating to animals (keeping of domestic animals, animal protection movement, establishment of zoos, etc.). If we follow the history of relationships between people and animals, we can see that in the peasant world the demarcation line between human and animal was less strict than in the modern world. For example, domestic animals were indicators of the peasants' social and economic status; they lived side by side with people and in the cold season often even shared the same room (see also Costlow \& Nelson 2010). Nowadays, the former pragmatic perception of pets as property is being replaced with the view of pets as friends and companions. Attitudes towards animals depend in the first place on the general cultural context, and the time-related message that this tradition conveys reflects the change in people's relationship with nature, in this case pets. In this context, the children's horror story (Text 4), but even more so the graphic and moralising media text (Text 1 ) inspired by it, can be defined as a social narrative ${ }^{6}$ that reveals the unresolved social problems of the welfare society.

Nowadays, animals are treated not only as equals to people but also as weak and helpless. In 2001, for example, the term 'pet' and the rules regulating people's responsibilities towards pets were officially adopted (see Javoiš 2006). People have come to hold similar ritual celebrations in honour of their pets that are organised for humans (birthday parties, funerals) (see Torp-Kõivupuu 2004). At the same time, large cities are still faced with the problem of stray pets, especially cats that reproduce too freely and spread diseases. The same newspaper issue that published the report of the police spokesman, for example, also includes an article reporting that it had been decided that all stray cats in Pärnu were to be sterilised. 
From a narrative researcher's viewpoint, it is interesting to note that Texts 1 and 4 fit among the many contemporary urban legends that reflect similarly ambiguous attitudes towards cats. These are mostly rather cruel stories in which the relationships between humans and animals are not very positive and may have a tragic outcome for some characters of the story. ${ }^{7}$ Many urban legends that are popular in the Estonian tradition tell about dead cats that are taken to the countryside to be buried, but are mistaken for something else. There is a story about how a cat run over by a neighbour's car was mistakenly considered a victim of food poisoning, etc. Cats are nice and cute, but do they really belong into our flats or even beds, and are we not overly personifying them? Is it necessary to call a fire brigade every time we see a cat on a roof? Finnish folklorist Leea Virtanen, who has studied legends among the adults' repertoire and children's horror stories, is convinced that the message of such accident stories is that we should not treat animals like humans. The place of dogs and cats is outside, and we should be masters of our own house (Virtanen 1996: 184).

Many belief legends that were popular in the agrarian culture basically reflect the same idea: on the one hand, they express a pragmatic perception towards pets, while on the other they stress that a pet, like all the nature around us, must be treated with respect. Even today people are familiar with belief legends according to which the person who damages a bird's nest or tortures an animal will be punished (Salve 2007: 61-63). Leea Virtanen (1996: 66) points to a story popular among Finnish schoolchildren in the 1990s, which speaks about a cat's revenge on two boys who killed her kittens - she scratches one of them blind and drops a stone to the other's head.

However, in the first and fourth examples, the case could be that for the today's schoolboy speaking about his 'hunting trip' is a tall tale similar to the ones told by the hunters in the distant past.

In a way, these lie stories seem to belong to our time, yet in another way they do not because we tend to judge them according to the cultural norms and moral criteria of the modern society. It seems that for the people of our century, the Munchausen tales are simply tales of animal cruelty and lies. There is an interesting documented case in Estonia: a member of a commission that was created within the framework of the Library Act in 1923-19248 found in 1935 that the tales of Munchausen are not suitable for Estonian libraries because "[t] here are many lies in this book. And there is much animal torture" (Veskimägi 2000: 44).

The BNS news initiated various and contradictory opinions from the readers in the Internet comments. They pointed on the untrustworthiness of the media and the police, problems with stray animals and the homeless, and wondered 
about the truthfulness of the story. However, many of the comments proved that this kind of tradition was generally known.

- Are the police stupid or are they just pretending? Unbelievable.

- But this description is also crazy - to skin cats like that! Whatever for did the newspaper publish it? Some psychos might hit on the idea and then be disappointed that the skin won't peel off.

- I heard about this trick that boys performed already some five years ago. Frankly speaking, it was a grownup man who boasted about it and said that it was a spectacular sight.

- Congratulations to investigative journalism! By the way, women in sauna gossiped that in Rapla (town in Estonia) hunters had skinned a bear the same way! (Postimees, March 8, 2005)

- Estonian press bases its articles on the information from a reliable agency NSR ('naised saunas rääkisid' (women gossiped in sauna)).

- All kinds of idiots are published in the newspaper??? Damn the scraggy cats wandering about. Torturing animals is not a nice thing to do, but damn it, I also have problems with neighbourhood cats, they come and pee around my house ... damn it, everyone knows how disgustingly cat piss stinks; air gun doesn't help, probably have to set a bear trap under the snow.

- This T-shaped cut was an issue already in the $1980 \mathrm{~s}$, in my childhood. This is rather an urban legend. (Delfi, March 8, 2005)

All above examples clearly illustrate the fact that the form and the message of a contemporary narrative can be very ambiguous. It is evident that a narrative text cannot be considered a single established statement, but it represents a dialogue with several different, contradicting voices. Linda Dégh and Andrew Vázsonyi suggest that the legend itself has not changed, but as we examine the legend in vivo, the 'new' changes in structure and meaning become apparent to us. This allows us to perceive different voices and understandings, every one of them expressing different viewpoints in the legend as far back into the past as the records enable us to trace its context (Dégh \& Vázsonyi 1971). 


\section{CONCLUDING REMARKS}

Today we can no longer tell if and to what degree the stories about turning animals inside out and making them jump out of their skins were told as tall tales or comic legends. There were probably enough people who wanted to believe these stories despite their knowledge of nature and animal physiology. Today the story is not quite the same, and, evidently, the form of the belief legend has become even more predominant.

Does the use and adaptation of old folktales help us to express our feelings and perceptions of the world around us? Or do the folktales reveal to us the hidden aspects of ourselves - our transformed sense of morality, ethics and hygiene, but also our ignorance? The answer is affirmative to both. But these narratives certainly show us that the contemporary culture is no longer the culture of the narrator that is born in the interaction of the storyteller and the audience and in which the cruelty of the old hunter's tale is hidden behind the storyteller's creative imagination and skill and behind the audience's understanding that "this cannot happen in real life". It is no longer the personified world where a clever human triumphs over a clever animal. Maarja Lõhmus argues that, when delving into the gist of the media myth, we should take a glance at the relationships between modern society and the media. "Media functions as a means of turning phenomena and processes into social and institutional ones and presents these as such." (Lõhmus 2009: 185) The modern culture is a media culture where the folktale is recounted with profuse realistic, graphic and shocking details, and this leaves us the impression of its eternal presence and endless possibilities.

This is the world we believe in. Linda Dégh has succinctly described the transformed relationship between the man and the legend:

There were times in which people could distinguish fantasy from reality, artistic imagination from everyday life. These were 'adult times', fabulous times that could cope with magic. Our time is increasingly becoming a legend-time in which reality intermingles with unreality, without the capability of discriminating one from the other. We live in a society that regards beliefs, daydreams, and hallucinations as feasible suggestions that can turn into reality. This is what we learn from legends and headline news. (Dégh 2001: 8)

It seems that while trying to make animals more human-like and the nature dependent on us, we have lost the moral balance between the human race and the animals. The debate about the equal rights for humans and animals and 
the abuse of the latter by the former; a public skinning of an animal by animal rights activists in Tallinn Town Hall Square, and a particularly atrocious killing of a cat during a teenagers' bottle-spinning game in a flat in Tallinn represent the reality of the 21 st century. ${ }^{9}$

\section{ARCHIVAL SOURCES}

RKM - Folklore collection of the Department of Folkloristics at the Estonian Literary Museum

\section{NOTES}

1 The article is supported by the state programme SF 0030181s08 "Narrative Aspects of Folklore. Power, Personality and Globalization".

${ }^{2}$ Karl Friedrich Hieronymus von Munchausen (1720-1797) was a German nobleman and military officer, who was famous for his fantastic lie stories and became a symbol of an outrageous bluffer and liar. The folktales that were allegedly told by Munchausen were published in English by R. E. Raspe and in German by G. A. Bürger already in the 1780s. Later on, Raspe's and Bürger's texts, and free compilations and adaptations of Munchausen-episodes that only partly corresponded to the original texts spread over the whole world. At the end of the 19th century the term munchauseniade was introduced among the literary circles (included in Brockhaus lexicon since 1872). With the publishing of anonymous chapbooks, the baron became something of a folkloristic character that anyone could use at their discretion. Nowadays the storyteller and the lying baron Munchausen is featured as the hero in many books, art and music pieces, theatre performances and films (see Jaaksoo 1992: 3-16). Further on the Munchausen tale cycle see Enzyklopädie des Märchens.

${ }^{3}$ Kotovasiia is an example of word play in Russian: kot - cat, katavasiia - a mess, a trouble.

4 By the way, the ATU does not mention this tale type occurrence in Estonia; yet, it exists in Finland (Uther 2004: 474).

5 Munchausen syndrome is a medical term for a mental disorder. A sufferer from this disorder repeatedly feigns physical or mental illness in order to draw attention and evoke sympathy. The patient's behaviour may include pathological lying, feigning illness, sometimes inflicting physical harm to themselves, falsifying medical tests, etc. See also http://www.clevelandclinic.org/health/health-info/docs/2800/2821.asp?index=9833, last accessed on April, 3, 2013.

6 Many scholars have argued that contemporary legends should be understood and interpreted in the context of social problems and anxieties. Donna Wyckoff turns the question round and argues that contemporary legend theory has utility in understanding the social problem(s). The theoretical background of the contemporary legend 
enables us to understand and evaluate the social contents and the rhetoric of the problems of today's society. Donna Wyckoff examined stories about sexual harassment from the viewpoint of the contemporary legend and called them "social narratives" (Wyckoff 1996: 364).

7 See also S. Hartwell's The Cat in Urban Mythology [online], available at: http://messybeast.com/urbancat.htm, last accessed on March 12, 2013.

8 The head of the commission was Estonian linguist and language reformer Johannes Aavik, and the aim of the commission was to ensure the availability of quality literature in the open libraries of Estonia.

9 See Postimees (Nov. 13, 2006) "Laupäevasel loomakaitsjate meeleavaldusel Tallinna vanalinnas läks rüseluseks" ('Public Unrest in the Animal Rights Activists' Protest in Tallinn Old Town on Saturday'), also Eesti Ekspress (Nov. 16, 2006). See SL Õhtuleht (March 30, 2007) “Kass kräunus, karvu tal enam peal ei olnud!" (The Cat Was Screaming, Its Hair All Gone').

\section{REFERENCES}

Ben-Amos, Dan 1976. Talmudic Tall Tales. In: Linda Dégh \& Henry Glassie \& Felix Oinas (eds.) Folklore Today: A Festschrift for Richard M. Dorson. Bloomington: Indiana University, Research Center for Language and Semiotic Studies, pp. 25-43.

Ben-Amos, Dan 2009. Talmudi luiskelood. [Talmudic Tall Tales.] Kommunikatsioon ja folkloor. Sator 9. Tartu: EKM Teaduskirjastus \& Eesti Folkloori Instituut, pp. 279-301.

BNS 2005. Artikkel kasside tapmisest põhines linnalegendil. [Article on Cat-Killing was Based on an Urban Legend.] Pärnu Postimees [newspaper], March 8, 2005.

Brunvand, Jan Harold 2002. Joke. In: Encyclopedia of Urban Legends. New York \& London: W.W. Norton \& Company, p. 223.

Costlow, Jane and Nelson, Amy 2010. Other Animals. Beyond the Human Russian Culture and History. Pittsburgh: University of Pittsburgh Press.

Dégh, Linda 1971. The 'Belief Legend' in Modern Society: Form, Function and Relationship to Other Genres. In: W. D. Hand (ed.) American Folk Legend: A Symposium. Publications of the UCLA Center for the Study of Comparative Folklore and Mythology. Berkeley: University of California Press, pp. 55-68.

Dégh, Linda 2001. Legend and Belief. Bloomington: Indiana University Press.

Dégh, Linda \& Vázsonyi, Andrew 1971. Legend and Belief. Genre, Vol. 4, pp. 281-304.

Dorson, Richard Mercer (ed.) 1939. Davy Crockett: American Comic Legend. New York, Spiral Press.

Enzyklopädie des Märchens: Handwörterbuch zur historichen und vergleichenden Erzählforschung 1999. Band 9, Magica-Literatur-Nezami. Berlin, New York: Walter de Gruyter, pp. 1008-1015.

Honko, Lauri 1986a. Empty Texts, Full Meanings. On Transformal Meaning in Folklore. In: B. R. Jonsson (ed.) ARV. Scandinavian Yearbook of Folklore 1984, Vol. 40, Uppsala: Almqvist and Wiksell, pp. 95-126. 
Honko, Lauri 1986b. Folkloristic studies on meaning. In: B. R. Jonsson (ed.) ARV. Scandinavian Yearbook of Folklore 1984, Vol. 40, Uppsala: Almqvist and Wiksell, pp. 35-56.

Jaaksoo, Andres 1992. Eeskõne. [Introduction.] In: G. A. Bürger. Wabahärra von Münchhauseni imepärased reisid ja seiklused merel ning maal nii nagu ta ise nendest sõprade ringis veiniklaasi juures pajatas. [The Wonderful Travels and Adventures of Baron Münchhausen, as Told by Himself in the Company of His Friends and Washed Down by Many a Good Bottle of Wine.] Tallinn: Tiritamm, pp. 3-16.

Javoiš, Juhan 2006. Lemmikloomapidamine: õigustused ja vastuväited. [Keeping Pets: Justifications and Objections.] Mäetagused, Vol. 31, pp. 177-190. http://haldjas. folklore.ee/tagused/nr31/javois.pdf, last accessed on October 31, 2012.

Kollom, Inessa 2005. 'Kotovasiia' iunykh potroshitelei. Molodezh' Estonii [newspaper], 17 February. http://www.moles.ee/05/Feb/17/index.php, last accessed on October 31, 2012.

Lindahl, Carl 1996. Psychic Ambiguity at the Legend Core. In: G. Bennett and P. Smith (eds.) Contemporary Legend. A Reader. New Perspectives in Folklore, Vol. 4. New York and London: Garland Publishing Inc., pp. 69-90.

Lõhmus, Maarja 2009. Mediamyths: The Struggle to Influence Society through Journalism. In: M. Kõiva (ed.) Contemporary Folklore IV. Tartu: ELM Scholarly Press, pp. $185-194$.

Meditsiinisõnastik 2004. Meditsiinisõnastik. Eestikeelsed terminid koos seletuste ning inglise ja soome vastetega. [Medical Dictionary. Estonian Terms with Explanations and English and Finnish Equivalents.] Tallinn: Medicina.

Preston, Cathy L. 1997. Joke. In: Th. A. Green (ed.) Folklore. An Encyclopedia of Beliefs, Customs, Tales, Music, and Art, Vol. 2. Santa Barbara: ABC-CLIO Inc., pp. $471-475$.

Proodel, Mall 1969. Üks jahimees läks metsa. Valimik rahvajutte jahist ja metsloomadest. [A Hunter Went to the Woods. Selection of Folktales about Hunting and Wild Animals.] Tallinn: Eesti Raamat.

Röhrich, Lutz 1986. The quest of meaning in folk-narrative research. In: B. R. Jonsson (ed.) ARV. Scandinavian Yearbook of Folklore 1984, Vol. 40. Uppsala: Almqvist and Wiksell, pp. 127-138.

Salve, Kristi 2007. Kassi helge kuju eesti rahvapärimuses. [The Happy Image of the Cat in Estonian Folklore: How and Why?] Mäetagused, Vol. 35, pp. 47-94. http:// haldjas.folklore.ee/tagused/nr35/salve.pdf, last accessed on November 1, 2012.

Torp-Kõivupuu, Marju 2004. Risti peale kirjutas: Ühel papil oli peni...: Eesti loomakalmistukultuurist. [On the Estonian Pet Cemetery Tradition.] Mäetagused, Vol. 25, pp. 47-76. http://haldjas.folklore.ee/tagused/nr25/loomakalmistud.pdf, last accessed on November 1, 2012.

Uther, Hans-Jörg 2004. The Types of International Folktales. A Classification and Bibliography. Tales of the Stupid Ogre, Anecdotes and Jokes, and Formula Tales. Part II. FF Communications, No. 285, Helsinki: Suomalainen Tiedeakatemia.

Veskimägi, Kaljo 2000. Münchhausen...? Aga ta ju valetas! [Munchausen...? But He Lied, Didn't He?] Raamatukogu, No. 2, pp. 42-45.

Viikberg, Jüri 1997. Anekdoodiraamat. [Book of Anecdotes.] Tallinn: Eesti Keele Instituut. 
Virtanen, Leea 1996. Apua! Maksa ryömii. Nykyajan tarinoita ja huhuja. [Help! The Liver is Creeping!] Helsinki: Kustannusosakeyhtiö Tammi.

Wyckoff, Donna 1996. "Now Everything Makes Sense!": Complicating the Contemporary Legend Picture. In: G. Bennett \& P. Smith (eds.) Contemporary Legend. A Reader. New Perspectives in Folklore, Vol. 4. New York and London: Garland Publishing Inc., pp. 363-380. http://www.clevelandclinic.org/health/health-info/ docs/2800/2821.asp?index=9833, last accessed on November 1, 2012. 